
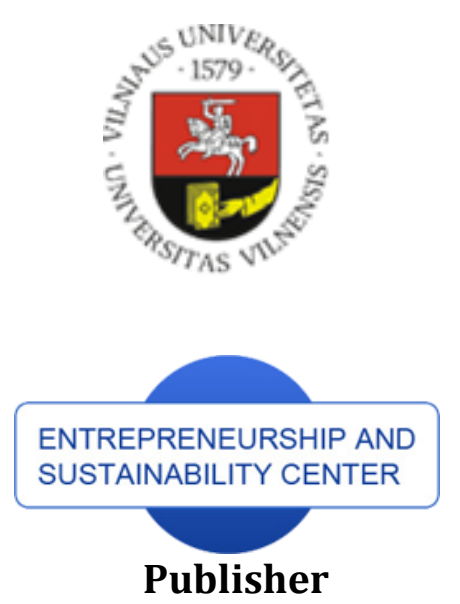

http://jssidoi.org/esc/home

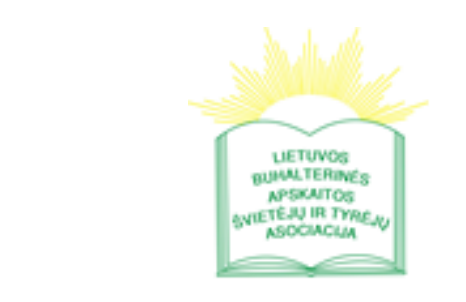

enterprise

europe

network

Business Support on Your Doorstep

CASPA

Scopus Web of Science

1 Clarivate

\title{
INTEGRAL ASSESSMENT OF DEVELOPMENTAL STABILITY: CASES OF LITHUANIA AND UKRAINE
}

\section{Liliya Filipishyna $^{1}$, Svetlana Bessonova ${ }^{2}$, Gerda Venckeviciute ${ }^{3}$}

\begin{abstract}
${ }^{I}$ Department of Economics and production organization of Pervomaisk Branch of the National University of Shipbuilding NUS, Pervomaisk, Ukraine
\end{abstract}

${ }^{2}$ Academy of Social Management, Priazovsky State Technical University, Mariupol, Ukraine

${ }^{3}$ Accounting and audit department, Faculty of Economics and business administration, Vilnius University, Lithuania

E-mails: ${ }^{1}$ ontariofilpi@ukr.net, ${ }^{3}$ Gerda.venckeviciute@ef.vu.lt

Received 30 March 2018; accepted 22 May 2018; published 30 September 2018

\begin{abstract}
The article highlights three directions of stable development: economic growth, ecological management, social integration which cover all the sectors of development. Main tasks and functions are presented in the context of stable enterprise and society development. They can be carried out with the help of certain indicators and applied in different countries, regions, or industries. Approbation of the proposed mechanism was carried out at Lithuanian waste management sector and Ukrainian metallurgical enterprises. The system of stable development indicators proposed by the authors includes three groups for Lithuanian waste management industry case and five groups of them for Ukraine metallurgical enterprises. The ISI - a stability index which is used for integral assessment of industrial enterprises' developmental stability, and is based on calculating complex indicators of economic, ecological, social, risk and market stability. The mechanism of integrated assessment of enterprise stability has been improved and now allows choosing the optimal continuous monitoring method, giving enterprises an opportunity to work effectively and develop steadily for a long period of time. Developmental stability corresponds to the average level and characterizes the need to develop the dimensions for increasing the level of developmental stability of such enterprises.
\end{abstract}

Keywords: stable development; integral assessment; indicators of stable development; waste management industry; metallurgical enterprise; mechanism of integral stability assessment

Reference to this paper should be made as follows: Filipishyna, L.; Bessonova, S.; Venckeviciute, G. 2018. Integral assessment of Developmental stability: cases of Lithuania and Ukraine, Entrepreneurship and Sustainability Issues 6(1): 87-99. http://doi.org/10.9770/jesi.2018.6.1(7)

\section{JEL Classifications: M40}

Additional disciplines: ecology and environment 


\section{Introduction}

Problem statement in general terms and its relation to essential scientific and practical objectives. The turbulence of the world economic system, globalization and convergence processes require the national industrial enterprises to find the ways to overcome the crisis and improve competitiveness, new sources of sustainable development and domestic economic growth. Thereby, it's especially important that the dynamic development of enterprises obtain the reporting in the sustainable development field. For sustainable development to be achieved, it is crucial to harmonize three interconnected core elements: economic growth, social inclusion, and environmental protection. Both, Ukrainian and Lithuanian enterprises just start to integrate the principles of sustainable development in their activities. Development of indicators system for sustainable development for many of enterprises is relevant primarily in connection with the deterioration of the environment and reducing the effectiveness of environmental solutions. The using of indicators developed by international organizations requires the large amount of information that is impossible to get in some cases. There's a need for improvement of the evaluation of sustainable development system which would open up the possibility for the business management and society to assess the effectiveness of the chosen strategy in the present context.

Analysis of recent researches and publications which initiated the solution to the problem and on which the author relies. The problems with ensuring economic stability of practical systems, economic development and growth were reflected in the works of foreign and domestic scientists: O. Amoshi (2012), B. Y. Parshin, Zielinski, T., Sagan, I., \& Surosz, W. (2017), J. Lonska (2017) etc. Their scientific works examined the issues of system determination of essence of sustainable economic development and formation of strategic decisions. However, questions remain on the aspects of development of the mechanism for integrated assessment of sustainable development.

The purpose of the article is the development of the assessing sustainable development of industrial enterprises based on the use of integrated indicators of sustainability (economic, environmental, market, risk, social) for improvement in effectiveness, increase of the competitiveness level and social responsibility of the enterprise. Selection of the unsolved parts of the main problem, which are dedicated to this article. The study of the problem of development of economic systems is one of the central problems in economics. At the same time, it requires further development of the methodology of evaluation of sustainability of industrial enterprises, which would take into account the impact of their activities on society. Statement of the issue is to improve the integrated assessment for sustainable development of industrial enterprises and propose indicators where the diagnosis of the management strategy of sustainable development of the enterprise can be carried out.

The methodology of the research is based on the combination of the theories of management of economic systems in conditions of globalization, convergence and transnationalization of the market economy. The empirical basis of the research of domestic and foreign scientists on the problems of formation and development of the sustainable economic development of industrial enterprises, the statistical reporting, public reporting of companies in the Internet environment, data of the international media organizations, the legislation of Ukraine and Lithuania on questions of regulation of economic activities of enterprises. During the research the following methods have been used: analysis and synthesis (in the research of the organizational forms and entity management structure sustainable development of industrial enterprises), System generalization (in determining the mechanism of the formation of the corporate social responsibility of the enterprises in conditions of sustainable development), statistical and correlative analysis (when grounding the directions of development for conducting economic analysis of industrial enterprises), the comparative analysis (when covering the features of the feasibility assessment of sustainability and effective activity of industrial enterprises at the stage of building the sustainable business development and society). The presentation of the main research material with full justification of scientific results. Basis of achievement of competitive advantage of the entity, in the conditions of economic instability is the observance of the principles of sustainable development. Tools which can estimate stability of development are the indicators of sustainable development. The authors note that the sustainable development indicators are the indicators that are output from the primary information and allow you to judge 
the condition and / or changes in the parameters of sustainable development. Also, it considers that indexes of sustainable development are the complex indicators received during aggregation of several indicators with each other or with other data (Filipishyna, 2017).

\section{Construction of sustainable development indicators}

Openness about the impact of enterprise activity on sustainability, the environment and society is of interest to stakeholders. We consider the observance of the imperative of openness, regarding stability, expedient in applying systematic concepts, unified terms and indicators. Based on these investigations we have identified three areas of sustainable development - economic growth, environmental management, social integration, which include all development sectors (infrastructure, resources, agriculture, etc.). Actualization of the development issue, which roses before countries, regions and corporations, primarily caused by variability of methods of formation and implementation of their strategies. On the basis of the carried-out analysis of the international experience in the field of constructing the system of ecological and economic indicators, we allocated two approaches (Sustainability review, 2015): 1) creation of the integrated, and aggregated indicators, which allow to estimate the level of stability of social and economic development (usually aggregating is performed based on three groups of indicators ecological and economic; ecological and social economic; ecological), 2) creation of system of indicators, each of which reflects separate aspects of sustainable development.

Indicators of sustainable development shall reflect economic, social, and ecological aspects of the requirements satisfaction of modern generation without restriction of needs of future generations, on satisfaction of own requirements. Sustainable development of industrial enterprises should be provided with sustainable economic growth, in conditions of its balance with the needs of society. The analysis of works of the leading scientists in this direction allowed to allocate the tasks which are intended for the solution of questions in the context of sustainable development of the entity and society (Bobylev, 2007; Amosha et al., 2012; Vinogradova, 2015; Parshin, 2016; Tvaronavičienė et al. 2018; Tvaronavičienè 2018; Mishenin et al., 2018).

1) Definition of objectives:

- identification of specific purposes of sustainable development policy in a quantitative form;

- development of strategies for future development;

- forecasting of effect of the planned actions.

2) Control:

- monitoring of goal achievement of sustainable development;

- evaluation of progress;

- evaluation of the effectiveness of the policy that was used previously;

- information for planning and making decision by the management of industrial enterprise and regional authorities;

- improvement of quality of management decisions at regional level taking into account line items and the interests of various national groups.

3 ) evaluation of the competitive position of the company within the country and in the world:

- interregional comparison, justification of transfers;

- relationship of the enterprise with the regional authorities, with the international community, attracting foreign investments, programs, and grants.

In the context of developing sustainable development policy functions of indicators of stability are as follows:

1. To determine the purposes which follow from the general concept of the strategic development program of the entity and don't conflict the regional strategic programs. In this regard, the indicators should reflect the level of achievement of key objectives and activities identified by the programs of the enterprise development and socio-economic development of the region. This will allow set the number of targets for each indicator.

2. To provide the basis for assessment of implementation process of these strategies for various levels (the technical and managerial purposes). Indicators give the chance to perform measurements, monitoring, assessment and the analysis of dynamics and efficiency of actions of goal achievement of sustainable 
ENTREPRENEURSHIP AND SUSTAINABILITY ISSUES

ISSN 2345-0282 (online) http://jssidoi.org/jesi/

2018 Volume 6 Number 1 (September) http://doi.org/10.9770/jesi.2018.6.1(7)

development. The specified will allow to transfer the responsibility for achievement of certain individual target indicators of various departments (for example, indicators of the state of health or employment of the population) and to perform (partial) efficiency evaluation of activities of certain structure elements of public administration for goal achievement of policy.

3. To provide transparent informing of society on strategy implementation and dynamics of actions for achievement of sustainable development.

The critical analysis of literature references, proved that during the using of foreign experience and techniques of creation of ecologic and economic indicators for the industrial enterprises it's necessary to consider the specifics and economic features of the country. However, the correction of the traditional economic indicators, considering the environmental factors may cause the significant reduction. Results of industrial enterprises activities influence the dynamics of all elements of sustainable development of the country, which actualizes the study of problems in area.

\section{Case of selected countries and industries}

In this article, the development of integrated assessment of development stability is performed on the case of Lithuanian waste management industry, which includes 100 enterprises, and Ukrainian metallurgical entities, which take 7 huge, large and medium enterprises. These sectors are important integrating factors of the countries' economic growth. The structure of the waste management and metallurgical sectors is the defining in appeal level of new kind of business that will cause the emergence of new workplaces, replenishment of budgets with taxes, improvement the quality of life etc. So, the development of primary link of economy - industrial enterprise is the basis of strategy of sustainable economic development of the state. The interaction of the economic, social, and environmental dimensions and their importance to sustainable development is shown in the Figure 1.

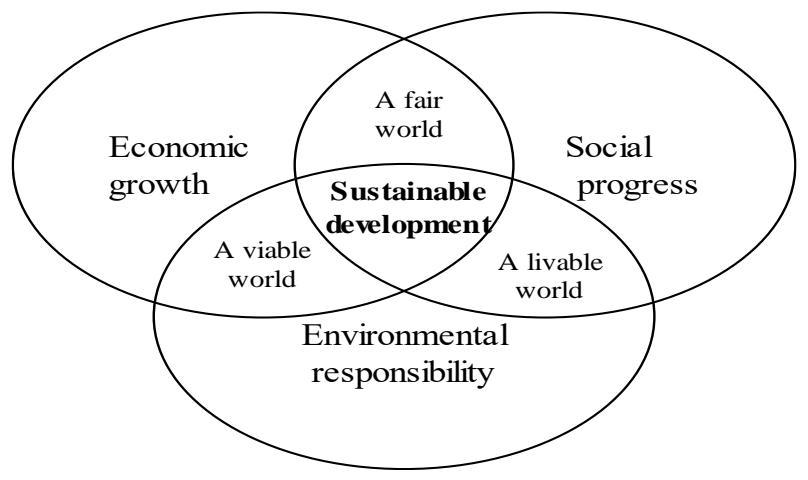

Fig. 1. Sustainable development dimensions

Source: European Commission, 2015

As it is shown in Figure1, it can be made the conclusion that it is crucial to harmonize three core sustainable development's elements: economic growth, social progress, and environmental responsibility to achieve sustainable development. Though practically, availability limits the final choice of indicators (Figge et al., 2006; Manzhynski et al., 2015).

The inter-connection between economic growth and the sustainable development is complex. Economic growth involves the combination of different types of capital to produce goods and services. The maintenance of all types of capital is essential for the sustainability of economic growth. Therefore, the financial analysis of Lithuanian waste management sector was performed to evaluate the tendencies of development of the sector industry (see Table 1). 
The International Journal

ENTREPRENEURSHIP AND SUSTAINABILITY ISSUES

ISSN 2345-0282 (online) http://jssidoi.org/jesi/

2018 Volume 6 Number 1 (September) http://doi.org/10.9770/jesi.2018.6.1(7)

Table 1. Lithuanian waste management industry's revenues and net profit variation in 2014-2016 year

\begin{tabular}{|l|r|r|r|r|r|}
\hline & \multicolumn{1}{|c|}{2014} & \multicolumn{1}{|c|}{2015} & $\begin{array}{c}\text { Variation } \\
2014 / 2015\end{array}$ & $\begin{array}{c}\text { Variation } \\
2015 / 2016\end{array}$ \\
\hline Sector revenues, Eur & 472461218 & 446049645 & $-5,6 \%$ & 419417095 & $-6,0 \%$ \\
\hline Median of sector revenues, Eur & 2345003 & 2596576 & & 2202461 & \\
\hline Sector net profit, Eur & 10922053 & 5048576 & $-53,8 \%$ & 15708377 & $211,1 \%$ \\
\hline Median of sector net profit, Eur & 30892 & 26889 & & 31462 & \\
\hline
\end{tabular}

Source: composed by authors based on Lithuanian credit bureau data

As it is shown in the table above, although the revenues of this industry are constantly decreasing in last three years, in recent years the profit has increased significantly. It enables to conclude that enterprises managed to improve the effectiveness of internal processes and so to increase net profit. In order to accomplish multidimensional integral assessment of developmental stability, three sustainable development levels were defined (see Table 2) and used in the assessment of Lithuanian waste management sector process.

Table 2. Sustainable development levels

\begin{tabular}{|c|c|c|c|}
\hline Dimension & Low importance & Average importance & High importance \\
\hline $\begin{array}{c}\text { Environmental } \\
\text { dimension }\end{array}$ & $\begin{array}{c}\text { Minimum or not at all } \\
\text { importance to the } \\
\text { environment }\end{array}$ & $\begin{array}{c}\text { Significant importance } \\
\text { to the environment }\end{array}$ & $\begin{array}{c}\text { High importance to the } \\
\text { environment }\end{array}$ \\
\hline Social dimension & $\begin{array}{c}\text { Minimum or not at all, } \\
\text { insignificant concernment } \\
\text { of society or stakeholders }\end{array}$ & $\begin{array}{c}\text { Significant concernment } \\
\text { of society or } \\
\text { stakeholders }\end{array}$ & $\begin{array}{c}\text { High importance, } \\
\text { obvious concernment of } \\
\text { society and stakeholders }\end{array}$ \\
\hline Economic dimension & $\begin{array}{c}\text { Minimum or not all all } \\
\text { financial importance }\end{array}$ & $\begin{array}{c}\text { Significant financial } \\
\text { importance }\end{array}$ & $\begin{array}{c}\text { High financial } \\
\text { importance }\end{array}$ \\
\hline
\end{tabular}

Source: composed by authors

After assessment of sustainable development in Lithuanian waste management industry under questionnaire based study, the diagram (see Fig. 2) was composed. As it is shown in the diagram below, the lowest importance in Lithuanian waste management industry still are environmental and social dimensions which indexes are equal to 2,575 and 2,6 - these are evaluated as higher than average, whereas economical dimension index reaches 2,818 and is defined as high importance.

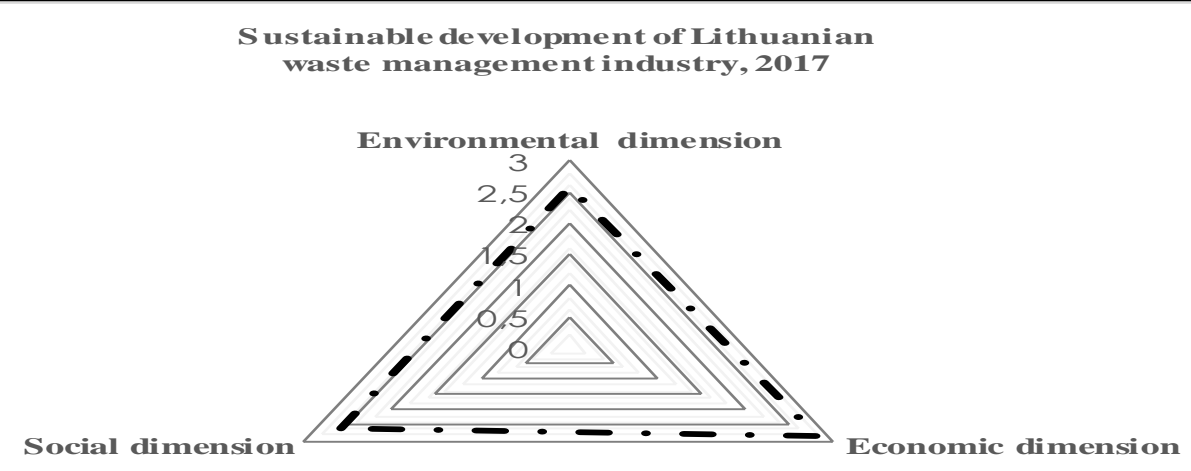

Fig. 2 Sustainable development of Lithuanian waste management industry, 2017

Source: composed by authors

In the second part proposed by the authors system of indicators of sustainable development when adapted to Ukrainian metallurgical entities, includes five groups of indicators: 
ENTREPRENEURSHIP AND SUSTAINABILITY ISSUES

ISSN 2345-0282 (online) http://jssidoi.org/jesi/

2018 Volume 6 Number 1 (September) http://doi.org/10.9770/jesi.2018.6.1(7)

- economic which influence tendencies of development of the sector industry;

- social that allow to assess the level of social development and the subordination of goals of economic growth with priorities of the implementation of social development programs;

- environmental parameters that determine the effect on the volume of industrial production on the environment;

- risk - which determine internal property of system, that promotes preserving its integrity as a result of various impacts on external and internal environment;

- market - that interact between the industrial enterprise and society.

The information base of the evaluation of each component is formed by the factors, the quantitative values of which must be set based on the statistical information (see Table 3).

Table 3. Indicators of the statistical information for the integrated assessment of sustainable development of industrial enterprise

\begin{tabular}{|c|c|c|c|c|}
\hline $\begin{array}{l}\text { Economic } \\
\text { indicators }\end{array}$ & Social indicators & $\begin{array}{l}\text { Environmental } \\
\text { indicators }\end{array}$ & Risk indicators & $\begin{array}{l}\text { Market } \\
\text { indicators }\end{array}$ \\
\hline $\begin{array}{l}\text { the index of industrial } \\
\text { production; } \\
\text { volume of capital } \\
\text { investments; } \\
\text { the amount of state } \\
\text { support of investment } \\
\text { projects in the industry; } \\
\text { the number of } \\
\text { innovative enterprises; } \\
\text { profitability; } \\
\text { presence and level of } \\
\text { depreciation of the basic } \\
\text { means. }\end{array}$ & $\begin{array}{l}\text { quantity of the } \\
\text { created workplaces; } \\
\text { size of the average } \\
\text { monthly salary of } \\
\text { workers in industry; } \\
\text { wage arrears; } \\
\text { level of work- } \\
\text { related injuries; } \\
\text { skill level of staff }\end{array}$ & $\begin{array}{l}\text { the volume of toxic } \\
\text { waste and emissions } \\
\text { into the air; } \\
\text { the number of } \\
\text { resource-and energy- } \\
\text { saving and low-waste } \\
\text { technologies; } \\
\text { the number of } \\
\text { environmental } \\
\text { measures }\end{array}$ & $\begin{array}{l}\text { the quality and } \\
\text { reliability of the } \\
\text { enterprise } \\
\text { (organizational } \\
\text { structure, material } \\
\text { flows, technology, } \\
\text { qualified } \\
\text { personnel, etc.), } \\
\text { the ability to } \\
\text { withstand extreme } \\
\text { internal and } \\
\text { external loads }\end{array}$ & $\begin{array}{l}\text { availability of the bodies } \\
\text { exercising sustainable } \\
\text { management; } \\
\text { availability of the } \\
\text { legislative frameworks on } \\
\text { sustainable development; } \\
\text { cost of maintaining the } \\
\text { bodies to administer } \\
\text { sustainable development } \\
\text { the number of social } \\
\text { infrastructure of } \\
\text { manufacturing enterprises }\end{array}$ \\
\hline
\end{tabular}

For complex assessment of entity stability, the mechanism which includes the choice of an optimum method of continuous monitoring, that allows industrial enterprises to work effectively and to develop steadily during the long period of time, is used. This process includes collecting data that tracks the dynamic changes of the condition of the company and identify the trends of its development. The mechanism of complex assessment of sustainable development of the enterprise it's recommended to implement in phases as is shown in Figure 3. Each stage consists of several operations, which are interconnected. 
The International Journal

ENTREPRENEURSHIP AND SUSTAINABILITY ISSUES

ISSN 2345-0282 (online) http://jssidoi.org/jesi/

2018 Volume 6 Number 1 (September)

http://doi.org/10.9770/jesi.2018.6.1(7)

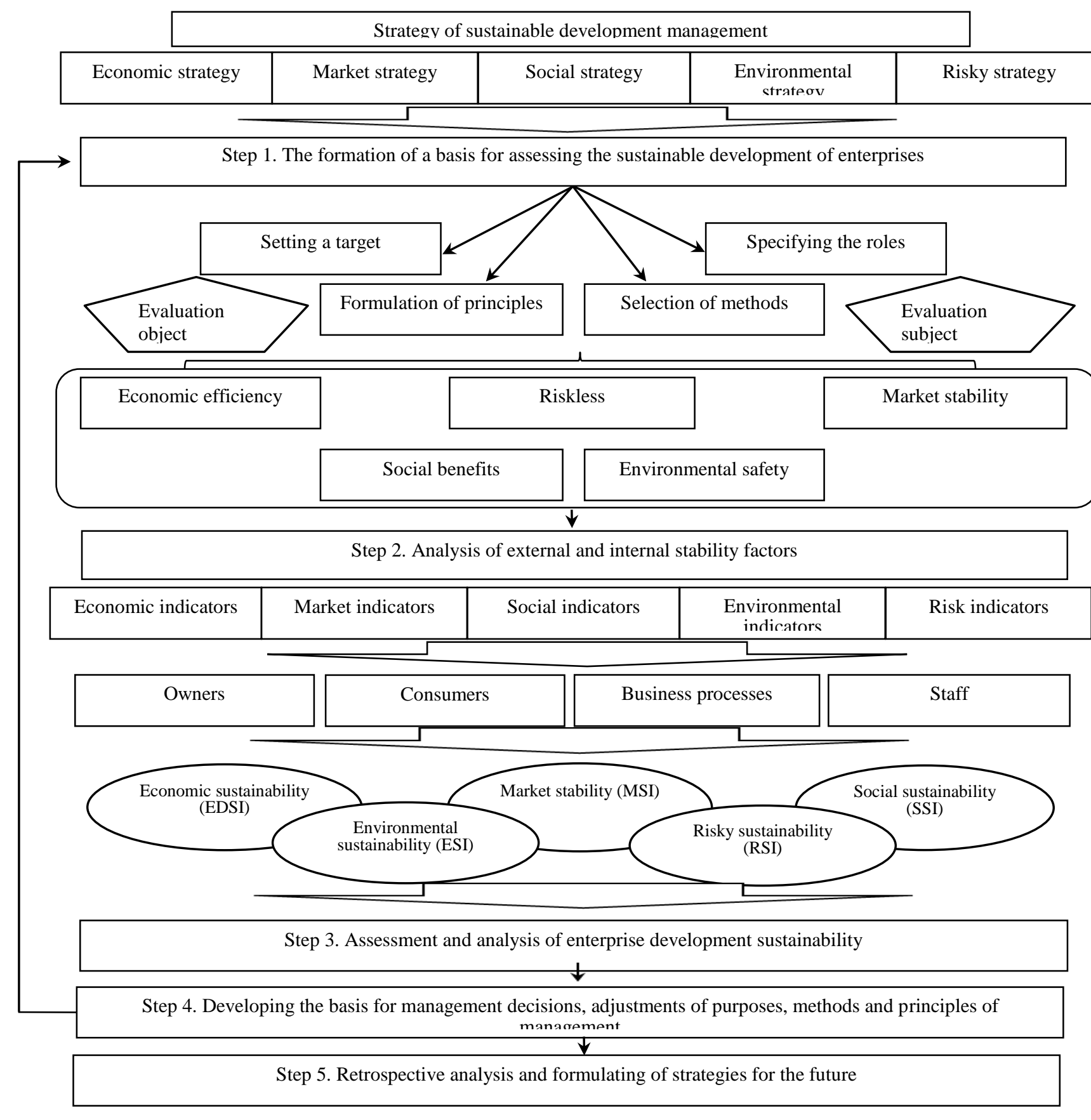

Fig. 3 Mechanism for integrated assessment of sustainable development of enterprises

Source: composed by authors based on N.A. Khomyachenkova (2010), N. V. Shmeleva (2013)

To apply the proposed indicators, we're using the sustainability index of the metallurgical entity development (ISI), which we supplement with a complex indicator of market stability which characterizes preferences of consumers and considers and takes into account the market mechanisms and estimates the level of adoption of development programs of the entity by society. The index of sustainability is based on the geometric average of integrated indicators of economic, environmental, social, risk, and market sustainability. 
ENTREPRENEURSHIP AND SUSTAINABILITY ISSUES

ISSN 2345-0282 (online) http://jssidoi.org/jesi/

2018 Volume 6 Number 1 (September) http://doi.org/10.9770/jesi.2018.6.1(7)

$I S I=\sqrt[5]{E D S I * S S I * E S I * R S I * M S I}$

(1), where

EDSI - is the economic sustainability

SSI - social sustainability

ESI - ecological sustainability

RSI - risky sustainability

MSI - market sustainability

Interpretation of the index and characteristics of its condition is proposed to conduct with usage of descriptions of the elements of sustainability of the enterprise presented in Table 4 (Filipishyna, 2017).

Table 4. Description of the sustainability of the enterprise

\begin{tabular}{|c|c|c|c|}
\hline Class resistance & $\begin{array}{l}\text { The value of the } \\
\text { index }\end{array}$ & $\begin{array}{l}\text { Elements of } \\
\text { sustainability }\end{array}$ & Description \\
\hline \multirow{5}{*}{$\begin{array}{c}\text { Absolute } \\
\text { sustainable } \\
\text { development }\end{array}$} & \multirow{5}{*}{$0,9<\mathrm{ISI} \leq 1$} & Economic & Economic situation highly effective \\
\hline & & Market & Balanced trade, price, sales policy \\
\hline & & Social & $\begin{array}{l}\text { The personnel is provided with the stable salary, the } \\
\text { optimum working conditions and rest are created }\end{array}$ \\
\hline & & Environmental & $\begin{array}{l}\text { All the environmental issues of industrial activity of the } \\
\text { enterprise are resolved }\end{array}$ \\
\hline & & Risky & The meeting its responsibilities by the entity \\
\hline \multirow{5}{*}{$\begin{array}{l}\text { The average } \\
\text { sustainable } \\
\text { development }\end{array}$} & \multirow{5}{*}{$0,6<\mathrm{ISI}<0,8$} & Economic & $\begin{array}{l}\text { The economic situation is provided by the stable technical } \\
\text { and economic indicators }\end{array}$ \\
\hline & & Market & $\begin{array}{l}\text { Stable promotion of product on the market, consumers are } \\
\text { loyal to products of the company }\end{array}$ \\
\hline & & Social & $\begin{array}{l}\text { All the issues on the social protection and security } \\
\text { personnel are solved }\end{array}$ \\
\hline & & Environmental & $\begin{array}{l}\text { Is characterized by the amount of payments for } \\
\text { environmental pollution within the set limits }\end{array}$ \\
\hline & & Risky & $\begin{array}{c}\text { The company may have some difficulties with compliance } \\
\text { with treaty obligations }\end{array}$ \\
\hline \multirow{5}{*}{$\begin{array}{l}\text { Unsustainable } \\
\text { development }\end{array}$} & \multirow{5}{*}{$0,3<$ ISI $<0,5$} & Economic & Values of indicators aren't stable \\
\hline & & Market & The low competitive capacity, market position isn't stable \\
\hline & & Social & Social security of the staff isn't provided \\
\hline & & Environmental & Is weak \\
\hline & & Risky & Enterprise is prone to failure to perform its obligations \\
\hline \multirow{5}{*}{ Crisis condition } & \multirow{5}{*}{ ISI $<0,2$} & Economic & $\begin{array}{c}\text { Is characterized by disruptions in production and business } \\
\text { activities, output is irregular, the sale of previously } \\
\text { produced goods isn't carried out }\end{array}$ \\
\hline & & Market & $\begin{array}{l}\text { The sale of previously produced goods isn't carried out, } \\
\text { economic relations aren't reliable }\end{array}$ \\
\hline & & Social & The significant job losses, high wage arrears \\
\hline & & Environmental & Isn't ensured \\
\hline & & Risky & $\begin{array}{l}\text { The company isn't able to fulfill contractual obligations } \\
\text { itself }\end{array}$ \\
\hline
\end{tabular}

Source: composed by authors based on L.M. Filipishyna, 2017 
ENTREPRENEURSHIP AND SUSTAINABILITY ISSUES

ISSN 2345-0282 (online) http://jssidoi.org/jesi/ 2018 Volume 6 Number 1 (September) http://doi.org/10.9770/jesi.2018.6.1(7)

The implementation of groups of enterprises with the subsequent analysis of the obtained results allows reveal regularities, characteristic features of financial and economic state of the enterprises included to the particular group. These findings can be used by management for management decisions, as well as public authorities in the preparation of development programs or the reform of enterprises, the development of effective measures to support enterprises, can also be used in the development of targeted regional programs.

The metallurgical enterprises for the evaluation of the sustainability index were analyzed according to the grouping of the maps for strategic groups' method. Map of strategic groups is a schematic representation on a two-dimensional plane structure of the industry in the context of groups of competing companies, which occupy similar positions in the market and compete on the basis of competitive advantages and the same methods, by implementing similar strategies using analogous resources. Enterprises belonging to the same strategic group can have such signs of kinship: comparable range of products; the same types of distribution channels; similar degree of vertical integration; equivalent service and technical assistance to customers; use of the almost identical qualities and characteristics of the product to related types and needs of buyers; intensive use of advertising in the media; dependence on identical technological approaches; the same prices and quality of products. The closer parameters of the competing companies are, the more carefully you should examine their activities since they are the main competitors within the same strategic group (Kaplan, 2007).

The analysis of strategic groups using the "maps of strategic groups in the industry" is performed in the following sequence:

1. They choose the most essential characteristics of the products or companies in the industry (according to analysis). There are two of them.

2. Make up the matrix card with these two characteristics. It's important that they are not correlated with each other.

3. They count selected features for a product or company, then the product or company are placed on a "map".

4. Objects that were close to each other, are combined in one strategic group.

5. They draw a circle around each strategic group (Kaplan, 2007; Kirich, 2012). It may be useful that total sales of the enterprises of strategic groups in the industry was proportional to the radius of the circle.

To illustrate the maps of strategic groups for the period 2016 is presented in the Figure 4 (Filipishyna et al. 2017; Filipishyna, 2017; Gonchar et al., 2017). 
The International Journal

ENTREPRENEURSHIP AND SUSTAINABILITY ISSUES

ISSN 2345-0282 (online) http://jssidoi.org/jesi/

2018 Volume 6 Number 1 (September) http://doi.org/10.9770/jesi.2018.6.1(7)

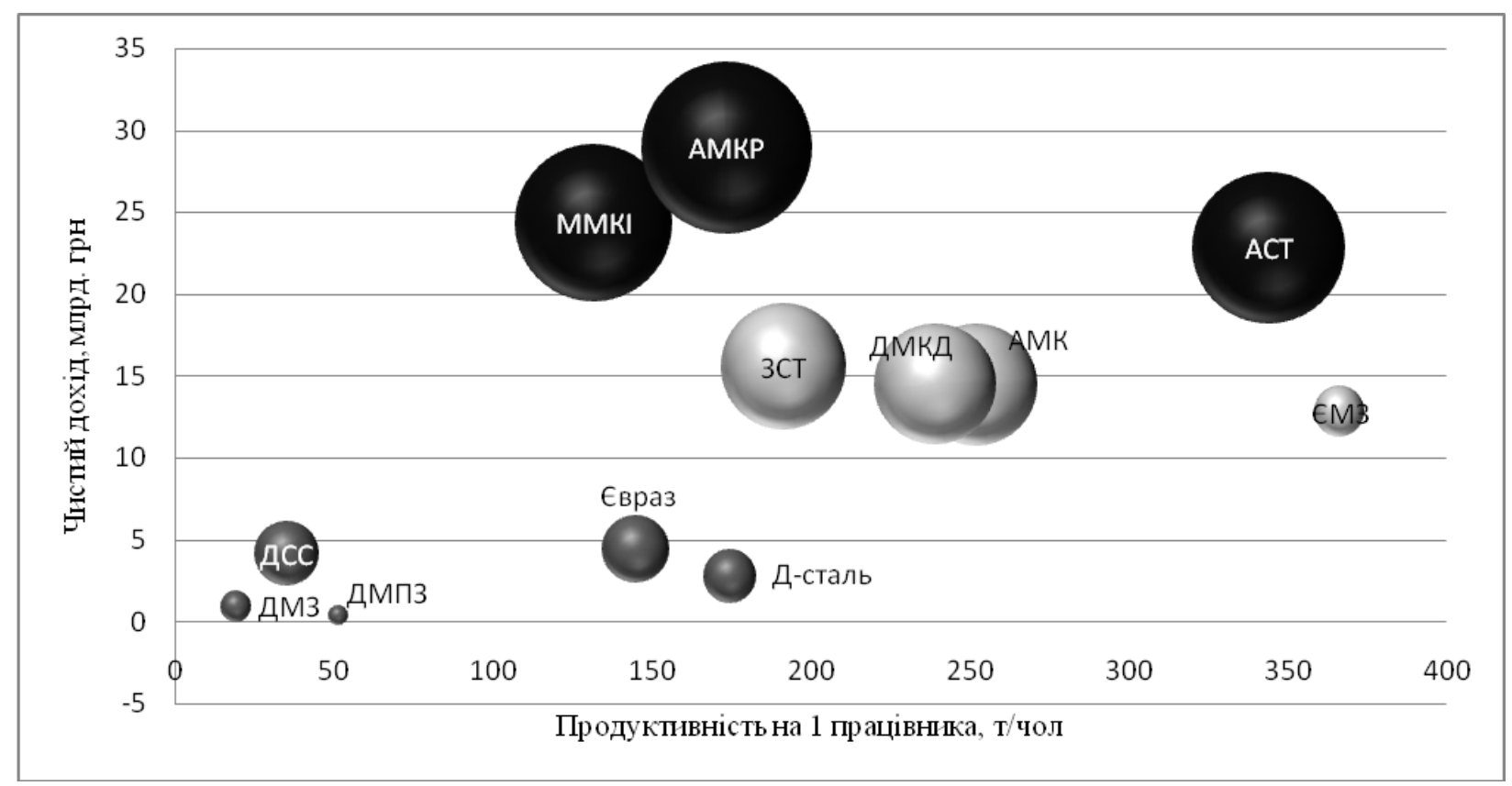

Fig. 4 The map of strategic groups of the enterprises of ferrous metallurgy in terms of productivity per 1 employee in 2016

(Чистий дохід.млрд.грн- Net profit.billion.UAH, Продуктивність на 1 працівника, т/чол- Productivity per 1 employee, t/person, AMКР- AMKR (Arcelor Mittal Kryvyi Rih), MМКI- MMKI (MMK named after Ilyich), АCT- Azovstal, 3СТ- Zaporizhstal, ДМКДDMPD (Dnieper Metallurgical Plant named after F. E. Dzerzhinsky), AMК- AMK, EM3- ESP (Electric Steel Plant), ДCC- DSS, ДM3DMP, ДМПЗ- DMPZ, Евраз- Evraz, Д-сталь- D-stal)

Source: composed by authors based on L. Filipishyna (2017)

The increase or decrease of certain groups and companies within the group is associated with the attainment or loss of competitive advantages. Companies can move to other strategic groups, when changing their parameters. The transition to another group requires a revision of the strategic balance, objectives and strategies of the enterprise. It's necessary to assess properly the place of the enterprise in the strategic group and its competitive environment. The group distribution was based for factors, which are reflected on the "y" axis which was supplied the criteria. It should be noted that this gradation is acceptable as to the position of enterprises on the market in 2016, and in 2001. The study obtained three groups of ferrous metallurgy enterprises (see Table 5).

Table 5. Groups of metallurgical enterprises as of 2016

\begin{tabular}{|c|l|}
\hline Name of the strategic group & \multicolumn{1}{|c|}{ Enterprise } \\
\hline \multirow{2}{*}{$\begin{array}{c}\text { Huge enterprises } \\
\text { (HE) }\end{array}$} & PJSC "MK "Azovstal" \\
\cline { 2 - 2 } & PJSC "MMK named after Ilyich" \\
\cline { 2 - 2 } $\begin{array}{c}\text { Large enterprises } \\
\text { (LE) }\end{array}$ & JSC "Arcelor Mittal Kryvyi Rih" \\
\cline { 2 - 2 } $\begin{array}{c}\text { Medium-sized enterprises } \\
(\mathrm{ME})\end{array}$ & PJSC "Dnieper metallurgical plant named after F. E. Dzerzhinsky" \\
\hline \multirow{2}{*}{\begin{tabular}{c} 
(HJSC "Electric steel plant "Dniprospetsstal" named after A. M. Kuzmin" \\
\cline { 2 - 2 }
\end{tabular}} & PJSC "EVRAZ - Dnepropetrovsk metallurgical plant named after Petrovsky" \\
\hline
\end{tabular}

The authors implemented the proposed mechanism for integrated assessment of sustainable development of industrial enterprises, the case of metallurgical enterprises. To analyze the sustainability there were investigated the indicators of the metallurgical enterprises of Ukraine for 2012-2016 which are divided into groups: huge, large and medium. For calculation of the generalized indicator of stability of development the formula (1) and the system of integral indicators of sustainable development and information of websites of mentioned enterprises are used (see Table 4). The data received in the result of analysis of the development level of the 
ENTREPRENEURSHIP AND SUSTAINABILITY ISSUES

ISSN 2345-0282 (online) http://jssidoi.org/jesi/

2018 Volume 6 Number 1 (September) http://doi.org/10.9770/jesi.2018.6.1(7)

entities are interpreted according to the scale of assessments of the generalized indicator of the sustainability of development (see Table 5). The analysis showed the highest resistance in the group of large enterprises (see Fig. $5)$.

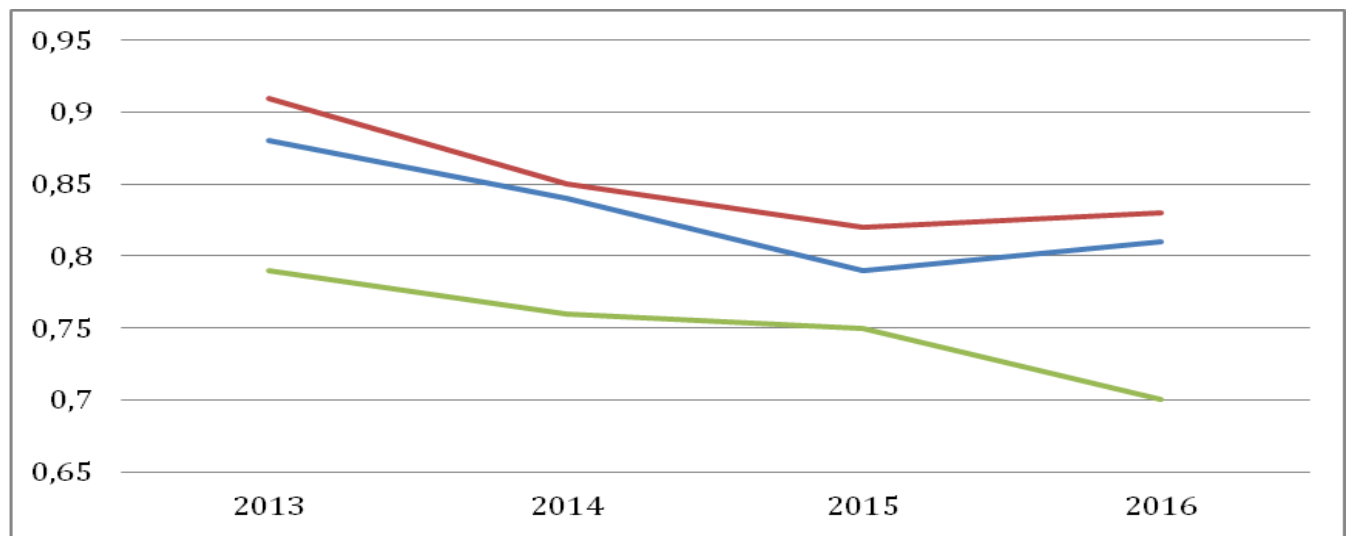

Group of huge enterprises; $\quad$ Group of large enterprises; $\quad$ Group of medium enterprises

Fig. 5. Dynamics of index of sustainable development on groups of the metallurgical entities (Huge/large/medium enterprises)

Source: composed by the authors based on L.M. Filipishyna et al., 2017

So, PJSC "Zaporizhstal", throughout the analyzed period had the highest value among all groups of the studied companies. The enterprises of the other groups have the following values, then the enterprises from the group "large".

\section{Conclusions}

It should be noted that the system of indicators of sustainable development offered by the authors facilitates the strategic dialogue between the entity and society towards sustainable development. The corporate system of indicators uses the integrated structure of results and output which is organized into the five-tire structure and groups the indicators into the chain of results. Consequently, the comprehensive assessment of sustainable development plays an important role in determining the sustainability index and classification of industrial enterprises according to the criterion of sustainability. Among benefits of the methodology it's possible to note that the weight of belonging of the entity to the certain class of decisions can be considered as probability of emergence of stability of the development inherent in this group of companies.

Thus, the proposed system of indicators allows assess the effectiveness of the company's strategies, including its business modernization, in the context of development results. It facilitates the strategic dialogue between the enterprise and society towards the sustainable development.

\section{References}

Amosha, O. I. 2012. Sustainable development of industrial region: social aspects: monograph. Academy of Sciences of Ukraine, Institute of economy of industry. Donetsk, p.534.

Association "Metallurgprom". [Electronic resource]. Retrieved from: http://www.metallurgprom.dp.ua/

Bobylev, S. N. 2007. Indicators of sustainable development: the regional dimension. Manual for regional environmental policy. M.: Acropolis, CEPR, p.60. 
ENTREPRENEURSHIP AND SUSTAINABILITY ISSUES

ISSN 2345-0282 (online) http://jssidoi.org/jesi/

2018 Volume 6 Number 1 (September) http://doi.org/10.9770/jesi.2018.6.1(7)

Figge, F., Hahn, T., Daverio, C., Persson, M., Brunczel, B., Wilhelm, A., \& Mauritz, C. 2006. Sustainable value of European industry: a value-based analysis of the environmental performance of European manufacturing companies. Institute for Strategic Research, scores und Sustainable Investment Research International.

Filipishyna L, Grishyna L, Zhuvagina I. 2017. Providing strategic stability of business structures in the conditions of the innovative development of the southern region of Ukraine. International Scientific and Practical Conference World Science. No 2, Vol. 3, p. $20-27$.

Filipishyna, L. M. 2017. Management of the system of sustainable economic development of the entities: theory, methodology and practice: monograph. Mariupol: SHEI "PSTU" p. 290.

Gonchar V.V., Khadzhynova O., Kalinin O. K 2017. Research on investment appeal and competitive capacity of industrial enterprises of Ukraine. Baltic Journal of Economic Studies, Volume 3 Number 5. Riga: Publishing House "Baltija Publishing". - p. 421-431

Kaplan R. 2007. Strategic maps. Transformation of intangible assets in material results / Robert Kaplan, Norton Dayvid. - M.: Publishing house the Olympus - Business, -520 p.

Khomyachenkova, N.A. 2010. Modern monitoring aspects of sustainable development of industrial enterprises: methodology and practice. Economic studies. Vol. 2. Retrieved from http://erce.ru

Kirich N. B. 2012. Improvement of the methodology of assessment of strategic capacity of the enterprise. Scientific bulletin of the Volynsk national university named after Lesya Ukrainka. No. 4 (229). - P. 67-71

Lonska, J. 2017. Sustainable Value Creation in Latvia, Lithuania and Estonia: Comparative Analysis of Economic Return from the Use of Economic, Social and Environmental Resources. In Proceedings of the 11th International Scientific and Practical Conference. No. 1, Vol.184, p. 191.

Manzhynski, S., Figge, F., \& Hassel, L. 2015. Sustainable Value creation of nine countries of the Baltic region. Value, changes and drivers. Journal of cleaner production, Vol. 108, p. 637-646.

Mishenin, Y.; Koblianska, I.; Medvid, V.; Maistrenko, Y. 2018. Sustainable regional development policy formation: role of industrial ecology and logistics, Enterpreneurship and Sustainability Issues 6(1): 329-341. http://doi.org/10.9770/jesi.2018.6.1(20)

Parshin Y. I. 2016. The strategy for the sustainable economic development of the national economy: theory, methodology and practice: monograph. Dnepropetrovsk: University named after Alfred Nobel. p.408.

Podlisnuk, V. 2005 The sustainable development of society: the role of education. Guidebook. K.: publishing house of the LDS "Kovalchuk", p. 88.

Science for Environment Policy, Indicators for Sustainable Cities, in-depth Report Produced for the European Commission. 2015

Environment by the Science Communication Unit, UWE, Bristol. Retrieved:

http://ec.europa.eu/environment/integration/research/newsalert/pdf/indicators_for_sustainable_cities_IR12_en.pdf

Shmeleva, N. V. 2013. Analysis of experience of building sustainable development indicators for industrial enterprises. Collection of works of International Scientific and Economics conference named after academician P. P. Maslova. Berlin: Wissenschaftliche Welte. Vol. 1. p. 227-239.

The world Bank. Electronic resource. - Access:

https://openknowledge.worldbank.org/handle/10986/13192/discover?filtertype=subject\&filter_relational_operator=equals\&filter=ECON OMIC+GROWTH

Sustainability review, 2015. Retrieved from: https://openknowledge.worldbank.org/handle/10986/22723

The official site of the association "Metallurgprom". [Electronic resource]. - Access: http://www.metallurgprom.dp.ua/

Tvaronavičienè, M. 2018. Towards sustainable and secure development: energy efficiency peculiarities in transport sector, Journal of Security and Sustainability Issues 7(4): 719-725. https://doi.org/10.9770/jssi.2018.7.4(9)

Tvaronavičienè, M., Tarkhanova, E., \& Durglishvili, N. 2018. Sustainable economic growth and innovative development of educational systems. Journal of International Studies 11(1): 236-244. https://doi.org/10.14254/2071-8330.2018/11-1/19

Vinogradova, N. A. 2015. Methods of evaluation of social development. Contemporary Economic Issues, https://doi.org/10.24194/11506 
ENTREPRENEURSHIP AND SUSTAINABILITY ISSUES

ISSN 2345-0282 (online) http://jssidoi.org/jesi/

2018 Volume 6 Number 1 (September) http://doi.org/10.9770/jesi.2018.6.1(7)

Zielinski, T., Sagan, I., \& Surosz, W. (Eds.). 2017. Interdisciplinary Approaches for Sustainable Development Goals: Economic Growth, Social Inclusion and Environmental Protection. Springer.

Lilyia FILIPISHYNA, has $\mathrm{PhD}$ in Economics, Associate Professor, Director of Innovation Centre, Associate Professor of the Department of Economics and production organization of Pervomaisk Branch of the National University of Shipbuilding NUS, (Pervomaisk) Ukraine.

ORCID ID: orcid.org/0000-0001-9552-1367

Svetlana BESSONOVA is an associate professor of accounting and audit, Ph.D, corresponding member of the Academy of Economic Sciences, academician of the Academy of Social Management. Priazovsky State Technical University, Ukraine (Mariupol).

ORCID ID: orcid.org/0000-0003-4938-3375

Gerda VENCKEVICIUTE has PhD in Business Management, is the assistant of an associate professor of accounting and auditing, Department of accounting and auditing, Vilnius university, Faculty of Economics and Business Administration, Lithuania (Vilnius).

ORCID ID: orcid.org/0000-0002-7374-8111

Register for an ORCID ID:

https://orcid.org/register

Copyright (C) 2018 by author(s) and VsI Entrepreneurship and Sustainability Center

This work is licensed under the Creative Commons Attribution International License (CC BY).

http://creativecommons.org/licenses/by/4.0/ 